\title{
CONSTITUTIONALISM AND DEMOCRACY: AN ISLAMIC PERSPECTIVE
}

\author{
Mohammad Hashim Kamali*
}

\begin{abstract}
The long history of Islamic scholarship on caliphate, sharī ah-oriented policy (siyāsah shar 'iyyah) and system of government (nizām al-hukm) has yielded a rich legacy which is, nevertheless, beset with uncertainties in conjunction with modern developments on government and constitutional law. Uncertainties have persisted over the basic concept and definition of an Islamic polity and the existence or otherwise of a valid precedent and model for an Islamic state. This is partially caused by a tendency in modern writings to apply the nation-state ideas of eighteenth-century Europe to the events of early Islam some twelve centuries earlier and doubtful parallels that have been attempted to be drawn between them. This article attempts first to identify the causes of the problem and then proceeds with an overview of the evidence in the Qur'ān and Sunnah and contributions of a cross-section of schools and scholars on the subject. This is followed by a general characterisation of an Islamic system of rule under five sub-headings, the first of which describing Islamic government whether Islamic state, and Iran in particular, is a theocracy, whether Islam stands for a qualified democracy, and whether it also upholds separation of powers. The last section discusses freedom of religion and religious pluralism in an Islamic polity followed by a conclusion and recommendations.
\end{abstract}

\section{Introduction}

Islamic government is essentially civilian rather than theocratic, notwithstanding the common misperceptions to the contrary. The theocratic image of Islamic state and government was in many ways portrayed by the post-revolutionary Islamic Republic of Iran, as I shall elaborate below. We shall also examine whether the Islamic system of rule can be described as a 'qualified democracy', one which also stands for freedom of religion and religious pluralism. Toward the end of this article we shall have a look at the recognition or otherwise of separation of powers, and to this effect examine two opposing theories on the subject. It is submitted that certain

\footnotetext{
* Professor Mohammad Hashim Kamali is the Chairman and CEO of IAIS Malaysia.
} 
functional lines of division between the various organs of state had always existed, and had subsequently been adopted - although not from the Islamic sources - by many of the twentieth-century constitutions of Muslim countries. My examination of the evidence in the sources supports the existence in principle of a strong and independent judiciary, and also of lines of separation between the executive and legislative branches of an Islamic government. Accountability under the rule of law and constitutional separation of powers thus bear essential harmony with the Islamic system of rule.

\section{Constitutionalism and Democracy Distinguished}

The twin concepts of constitutionalism and democracy normally nurture and endorse one another, yet they are not the same and can, under certain circumstances, stand in a state of tension. Whereas democracy is focused on majority rule, constitutionalism demands commitment to the rule of law. One also notes a tendency, on the part of the international community, to see the drafting of a constitution as a way toward a negotiated peace - especially in post-conflict situations. This may, theoretically, seem appealing, yet it could also run counter to its desired objectives and cause greater instability by accentuating the wishes of the majority of citizens over a suppressed minority. It may be relatively easy to impose elections on a given country, but it is more difficult to establish legality, commitment to basic rights, and a constitutional order of checks and balances within the organs of power. If democracy can be defined as "popular political self-government", a simple definition of constitutionalism could be "the containment of popular decision-making by a basic law". ${ }^{1}$ At the heart of constitutionalism lies the deliberate choice of a representative government to constitute its political life in terms of commitment to a binding agreement by the ruler and ruled, structured so as to be difficult to change. ${ }^{2}$ As American legal philosopher Ronald Dworkin (b. 1931) put it, "the constitution, and particularly the Bill of Rights, is designed to protect individual citizens and groups against certain decisions that a majority might want to make, even when that majority acts in what it takes to be the general or common interest". ${ }^{3}$ Apart from its obvious relevance in all societies, this aspect is particularly relevant in politically polarised and ethnically divided societies. Constitutions are drafted either at the end of a conflict to seal its outcome or prior to the eruption of conflict in an attempt to stave it off.

In Iraq, for example, the occupation powers attempted to forge a national and political reconstruction through the medium of a constitutional drafting. Through an inordinate amount of cajoling a document was drafted and ratified but the process of arriving there severely exacerbated existing divisions and yielded a document feared to ultimately lead to the disintegration of the state. ${ }^{4}$ Afghanistan could also be cited 
as a similar example, although different in some ways. However, the constitution that was drafted and ratified in January 2004 under the auspices of UNAMA(United Nations Assistance Mission for Afghanistan) has fallen short not only of its desired objective of facilitating a negotiated peace between the rival factions; it may have actually exacerbated factional rivalry and political instability in the country. In the midst of an on-going conflict, and against the background especially of a humiliating foreign occupation, it is questionable whether the process could live up to the expectations made of it. The same holds true for external attempts at mediation which sometimes pre-empt the emergence of a stable social consensus. This seems to be the case with external constitutional support given to political and military actors in the Sudanese and Somali civil wars. ${ }^{5}$

Commitment to justice, constitutionalism and judicial review can ultimately provide the necessary protection against the 'tyranny of the majority.' There is strong empirical evidence that constitutional legality will in time nurture democracy, but that democracy on its own will not necessarily bring a constitutionally committed government. Democracy and constitutionalism are not only different concepts but can exist in a state of tension, as the former advocates majoritarian preferences, whereas the latter imposes pre-existing restraints on the range of choices available to governing majorities. ${ }^{6}$

The Western experience since 1945 has largely embodied both democracy and constitutional government, making it thus difficult to imagine the two apart. Yet evidence shows that only in the late 1940s did most western countries become actually democratic, but that importantly, already a century earlier most of them had put in place significant constitutional elements such as the rule of law, private property rights, free speech and assembly and increasingly also constitutional separation of powers, without being democratic. Government in North America and Western Europe was not characterised by democracy but by constitutional legality. "The western model is best symbolised not by the mass plebiscite but the impartial judge." Some agreement seems to have developed over time that the best realisable form of government is a mixed - or constitutional - government in which freedom is constrained by the rule of law and popular sovereignty is tempered by state institutions that produce order and stability. ${ }^{8}$ Even if we do not conclude that democracy is simply not viable in an environment of intense ethnic preferences, it seems evident that merely holding elections is insufficient and that additional institutional mechanisms and constitutional restraints are necessary to make it work. The combined or mixed approach seems to show lines of convergence with the Islamic conception of a constitutional government that derives legitimacy from popular electoral mandate, commitment to justice and the rule of law - as discussed in the following pages. 


\section{Islamic Constitutional Law: An Overview of the Discipline}

Constitutional law is one of the most under-developed areas of Islamic jurisprudence and stands in this respect at the opposite pole of 'ibādāt (worship matters) on which juristic literature is exceedingly elaborate. A great deal of what has been written in the past concentrates on the early caliphate and pays but little attention to subsequent developments. The literature that has come about as a result is still wanting of critical evaluation and review. The prevailing uncertainties are also not entirely new as problems began to set in at an early stage. The nascent caliphate of the early decades of Islam had barely realised its potential when military conflict and irregularities of dynastic rule exposed it to intolerable disruptions. The originally republican features of the caliphate (khiläfah), especially consultation $(s h \bar{u} r \bar{a})^{9}$ and oath of allegiance (bay $a h),{ }^{10}$ were only nominally kept but were subjugated to the vagaries of a totalitarian system, which characterised the many centuries of rule under the Umayyads, the Abbasids and others.

'Abd al-Razzāq Aḥmad al-Sanhūrī observed in 1926 that in the field of constitutional law and government, the figh (Islamic law) had remained in a state of infancy. Abd al-Hamīd al-Mutawallī quoted him 50 years later to say that "the infant is still in the cradle. It can barely crawl and was never able to stand on its feet." " Hassan al-Ṭurābī (b. c.1932), a Sudanese religious and political leader, similarly noted that due to stagnation of constitutional law over the greater part of the Islamic history, comprehensive research and ijtihād (independent reasoning) in this area are wanting. ${ }^{12}$

A former Grand Mufti of Egypt, Shaykh Ahmad Huraydī, considered the political order that prevailed in the Muslim lands over the greater stretch of history from the Umayyads to the end of the Ottomans did not, on the whole, comply with the principles of Islam, and those who wrote on Islamic government remained focused on dynastic practices that did not reflect normative guidelines but expounded the history of government in those times, and there is "a big difference between the two". ${ }^{13}$

The Iranian Shi ite scholar Shaykh Ja far Subḥānī (b. 1922) concurred to say that al-Māwardī's renowned treatise al-Ahkām al-sulțāniyyah pays more attention to the realities of the Abbasid state of his time rather than the foundational guidelines of the Qur'ān and the sunnah. What needs to be done is to take a fresh recourse to those guidelines and avoid tainting them with the precedent of dynastic rule. ${ }^{14}$

P.J. Vatikiotis (d. 1997), the late Emeritus Professor of Politics at the School of Oriental and African Studies (SOAS) in the University of London, alluded to the Islamic resurgence of recent decades by saying that Muslims were critical of the prevailing "alien order which many consider unsuitable and inadequate for their societies [...]. One observes that neither in Iran so far nor among any of the militant 
Islamic movements elsewhere is there a clear idea of the nature of the Islamic state or government they wish to establish." 15

The contemporary Egyptian scholar, Muhammad Salīm al- 'Awwā, SecretaryGeneral of the International Union for Muslim Scholars, noted that the Islamic revolution of Iran stimulated scholarship and research on constitutional themes, yet "many issues of interest to Islamic political thought and constitutional law remain shrouded in ambiguity". It is perhaps the present generation of researchers whose contributions may "suit the requirements of our age and address issues of concern to us at present". ${ }^{16}$

Juristic works on the caliphate are on the whole concerned with the methods of designation of the caliph, his rights and duties and a certain institutional blueprint on the judiciary, vizierate, and departmental structures for the army, taxation, police duties and so forth. This literature on the whole is scanty on modern developments, including the nation-state itself, and constitutional themes on democracy, separation of powers and so forth. The remainder of this article will highlight the characteristic features of an Islamic polity.

\section{Characteristic Features}

Islam advocates a civilian polity which is neither theocratic nor totally secular but has characteristics of its own. It is a limited and a constitutional form of government whose powers are constrained by reference to the clear injunctions of the shari ' $a h$ on accountability and justice. It is also rooted in the notions of trust (amānah) and vicegerency (khiläfah) committed to administer justice and secure people's welfare (mașlahah). Thus according to an Islamic legal maxim, "the imām's (head of state) performance is judged by reference to people's welfare". ${ }^{17}$ This is the single most important criterion, in other words, by which to evaluate success or failure of a government in Islam. Is it also accidental, one might ask, to find that governments in Islamic history have been labelled by such names as caliphate, imāmate, sultanate, emirate etc., but not as 'Islamic State', a nomenclature which most likely appeared first in the writing of Muhammad Rashīd Riḍā (d. 1935)? This is because the Qur'ān and hadìth are silent on political nomenclature, and Muslim scholars have also shown sensitivity not to amalgamate state and religion together. The state represents the community to which it is accountable. It is a qualified electoral democracy that conducts its affairs through consultation and consensus. These are elaborated as follows.

\section{Government as a trust (Amānat al- $\mathbf{H} u \mathbf{k m})$}

Government in Islam is a trust (amānah) and an extension as such of the general qur'ānic concept expounded in a passage known as the ayyat al-umarā' '(the 'rulers' verse'), where we read: 
God commands you to render the trusts (al-amānāt) to whom they are due, and when you judge among people, you judge with justice. (4:58)

The immediately succeeding passage is on the subject of obedience where the text urges the faithful to "obey God and obey the Messenger and those in charge of the affairs among you" (4:59).

Muslims are thus enjoined to fulfil their trusts, to render impartial justice, and obey their lawful rulers. The renowned Qur'ān exegete al-Ṭabarī (d. 923) wrote that "the command over the fulfilment of trusts in this verse is addressed to community leaders $[\ldots]$ and those whom the community has entrusted with leadership, those who administer justice and manage the community's financial affairs". ${ }^{18} \mathrm{Al}$-Qurtubi (d. 1273), however, maintains that it is "addressed to all strata of society - especially the government leaders - regarding their duties in the distribution of assets as well as the administration of justice". ${ }^{19}$

Al-amānāt, in the above qur'ānic text, thus characterises the Islamic system of rule as a trust borne by its leaders and officials, which renders them accountable before God and the community. According to a hadìth:

Each of you is a custodian and responsible for that which is in his custody. The imām is a custodian and he is responsible for his subjects; a man is a custodian and he is responsible for his family, a woman is a custodian and she is responsible [...]. All of you are custodians of what is in their charge. ${ }^{20}$

It was on this basis that "the Righteous Caliphs understood their positions analogous to guardians and executors [...]. They saw it as their duty to personally supervise community affairs, protect their interests and their rights." ${ }^{21}$

Ibn Taymiyyah's (d. 1328) renowned book, al-Siyāsah al-shar 'iyyah (sharī'ahoriented policy), which is a commentary on the 'rulers' verse', highlights two themes in his elaboration of 'trusts': selection and appointment of officials, which must strictly be based on qualification and merit, and fair distribution of wealth. The reference to justice occurs immediately after 'al-amānāt', indicating that impartial justice is the most important of all amānāt. ${ }^{22}$

On distributive justice, Ibn Taymiyyah quoted the second Caliph, 'Umar b. al-Khațāā's (r. 634-644) statement on the assets of public treasury (bayt al-māl): "No one has a greater claim to these assets in preference to anyone else, and everyone's entitlement would be judged by his record (of service), his financial condition, his burdens and his personal needs." 23

Government as a trust is also manifested in the concept of khiläfah, which has two meanings, one being qur'ānic and refers to the vicegerency of man on earth (cf. $2: 30 ; 24: 55)$, and the other as a system of rule, which does not occur in the Qur'ān. ${ }^{24}$ 
Amānah, or trust, in government is also manifested in the notion of representation. The head of state is a representative (wakil) of the community by virtue of wakālah which is a fiduciary contract and a wakil is simultaneously a trustee in charge of the trust he bears on behalf of his principal. The wakil derives his authority from the principal (muwakkil) and exercises it on the latter's behalf. It is a restricted form of wakalah, manifested in the requirements that the Imām enforces the shari ${ }^{\prime} a h$ and consults the community in the conduct of government. ${ }^{25}$ Accountability (muhāsabah) continues down the command chain in that all government officials are accountable to the head of state by virtue of delegated authority (wilayyah or tawliyah) entrusted in them. No one has immunity and everyone, including the head of state, is accountable for their conduct. All are, in turn, subject to the authority of the courts of justice.

\section{Limited government}

Islam advocates a limited government in which the individual enjoys considerable autonomy. Restrictions are thus imposed on the state's legislative capacities, which may not introduce a law contrary to the injunctions of Islam. The state is also bound by the requirements of consultation and consensus, and enforcement also of the shari 'ah, which the state has no authority to overrule or abrogate. In the event where the government issues a command contrary to the injunctions of Islam, the individual is not bound to obey it. For according to a renowned hadith, "There is no obedience in transgression; obedience is due only in righteous conduct." ${ }^{26}$ The head of state represents the community that elects him in the first place and has authority to depose him when he violates the law. ${ }^{27}$

Islam does not advocate a totalitarian system as many aspects of civilian life remain outside the domain of law and government. Muslim jurists have thus distinguished the religious ( $\operatorname{din} \bar{\imath})$ from juridical ( $q a d \bar{a} \vec{a})$ obligations and maintained that only the latter are enforceable before the courts. Most of the religious aspects of the individual's life are private and non-justiciable. Even some of the religious duties such as prayer, fasting, the hajj, and almost all of what is classified as recommendable, reprehensible and permissible (mandūb, makrūh, mubāhh) are not legally enforceable. The private and civil rights of individuals are immune - by the express injunctions of the sharì $a h$ - against encroachment by others, including the state. No government agency - not even the sharí'ah courts - has the power to grant discretionary changes in the private rights and properties of individuals without their consent. ${ }^{28}$

The head of state as well as the judge enjoy but limited powers to grant a pardon to a convicted offender and may not order discretionary punishment for unstipulated violations. The deterrent ( $\left.t a{ }^{\prime} z \bar{i} r\right)$ punishments are open to court discretion in respect only of determining the quantitative aspect of the punishment for a conduct which 
is proscribed by the shari 'ah. Judges have no power to create offences without valid evidence. There is, moreover, no recognition in the shari' ah of any privileged individual or group and no one, including the head of state, enjoys special immunity or status before the courts. ${ }^{29}$ Thus it is noted that "the solutions provided by Islamic law go decisively and consistently in favour of the rights of the individual, of the sanctity of contracts, of private property, and they put severe limits to the action of the state in these matters".$^{30}$

In response to a question whether constitution-making was acceptable to Islam, Rashīd Riḍa issued the following fatwā which argued that since a constitution is designed to delineate the limits of the state power and clarify the state's commitment to rights of the people, it is acceptable to Islam. If enacting a formal constitution operates as a check on despotism, there is no question over its compatibility with the shari 'ah. In the event where the constitution contains rules that are repugnant to Islam, only the part that is so repugnant may be set aside but not the whole of it. Riḍa elaborated that in the writings of Muslim jurists one finds instances where they made errors in their ijtihād and in the books they have authored. One ought to isolate and reject the errors but not the whole of their endeavour. Errors must be corrected at an early opportunity so that the community is protected against deviation. The contemporary Egyptian scholar Mạ̣mud Ḥilmī Mușțafã has concurred with this fatw $\bar{a}$ and commented that there is nothing in the shar $\bar{l}^{-} a h$ against enacting a written constitution. $^{31}$

Government powers in Islam are also limited in respect of taxation. The sharì ah thus lays down the following:

1. taxation must be just and proportionate to the ability of the taxpayer;

2. it must apply equally to all without discrimination;

3. it must aim at the minimum of what is deemed necessary;

4. the well-being of the taxpayer must be observed in the determination of quantity and methods of collection; and

5. taxation must observe the time-limit of one calendar year for the yield or profit to materialise. ${ }^{32}$ Both the early Muslim jurist Abū Yūsuf (d. 798) and later on al-Māwardī (d. 1058) have emphasised moderation in taxation by stating that it must in no case deprive the taxpayer of the necessities of life. ${ }^{33}$

\section{Theocracy or civilian rule?}

If theocracy means government by religious leaders who exercise spiritual authority, such as that of the pope in the Middle Ages, then the Islamic system of rule does not qualify. In a theocracy the leaders claim to represent God and exercise powers such as the pardoning of sins. Islamic government is simply not vested with such authority ${ }^{34}$ for "Islam does not recognise a religious authority of the kind which 
is known in Christianity." ${ }^{35}$ Islam also encouraged the people to access the source evidence directly, and vested no one with the exclusive authority to interpret the Qur'ān nor to issue binding opinions in the name of religion. "The Islamic State", writes the contemporary Egyptian scholar Yūsuf al-Qaraḍāwī (b. 1926), "is not a theocracy: it is a civilian state (dawlah madaniyyah)", simply because it comes into being by election, pledge of allegiance (bay 'ah) and consultation, and the head of state is also accountable to the people. Citizens are entitled to advise the leader and alert him to his error. ${ }^{37}$

"It should be clearly understood", he writes, "that an Islamic state is not a theocracy"; it is not the government of the 'ulama ' nor is it a government by men only to the exclusion of women. Women played a considerable role in public life during the time of the Prophet, just as they also took part in the election of the third Caliph 'Uthmān (r. 644-656). ${ }^{38}$ In Islam, the government is committed to administer justice, protect the rights and liberties of the people and enable them to lead an honourable life. ${ }^{39}$ The state may take any form or model, provided that it enforces the shari 'ah. But that alone does not make the state a theocracy simply because the shari ${ }^{\prime} a h$ itself does not approve of theocratic government. ${ }^{40}$

Normative precedent on this is found in what is usually known as the 'Constitution of Medina' (c. 622) which laid the foundations of the new community under the Prophet's leadership. This document founded the bases of cooperation between the Emigrants (al-Muhäjirūn), the Helpers (al-Anșār) and the Jews. Issues of leadership and establishing the authority of the new state, equality and justice, freedom of religion, right of ownership, freedom of movement, war and peace, and combating crime were among the major preoccupations of this document. Thus we can see that the 'Constitution of Medina' did have pronounced civilian characteristics. ${ }^{41}$

The shari' 'ah is not all concerned with religious and worship matters; this is admittedly one aspect of it, but it is also concerned with issues of justice, rights and liberties, all with a degree of objectivity and inclusiveness that is not confined to Muslims but extends to all citizens. ${ }^{42}$

Theocracy demands unquestioning obedience - unlike the sharī'ah which recognises the individual's right to disobey an unlawful command, just as it also restrains the government from issuing one. ${ }^{43}$ Islamic government is thus described as a people's government (hukumah sha 'biyyah) wherein the ruler is under a mandate to administer justice and uphold people's basic rights in accordance with a set of objective rules. ${ }^{44}$

Al-Qaraḍāwi is of the view that the Islamic system is neither a theocracy nor is it totally secular ('ulmāniyyah). It has a duty to protect the religion and enable the people to observe it. The lawful and unlawful (halāl, harām), as are expounded in the shari ${ }^{\prime} a h$, are observed, and the state upholds religious values, yet it is not 
a theocratic state. All community members, men and women alike, are entitled to give sincere advice to the ruler and criticise the government. ${ }^{45}$

Two historical statements have, however, been cited, side by side with Iran's revolutionary experience, in support of the claim that Islam does actually advocate some sort of theocracy, one by the third caliph 'Uthman and the other by the Abbasid caliph al-Manșūr (754-775). These are as follows:

1. Prior to assassinating the caliph 'Uthmān (656), his assailants asked him to relinquish his position as caliph, which he declined and said "I shall not remove the garment God Almighty has adorned me with." Some commentators saw this as an affirmation, by the deceased caliph, of the religious character of the caliphal office, and the view somehow reverberated that the caliph was the chosen of God. ${ }^{46}$ The Mu tazilah rationalist school maintained that the caliph was an elected community representative who had no claim to holiness, a view that is now generally accepted: the slain caliph had said nothing during his 13 years in office to change the basic position that the caliph was accountable to the people, and his statement could simply be a pious acknowledgement of God's favour on him. $^{47}$

2. The Abbasid caliph al-Manșūr (r. 754-775) is quoted to have said in a sermon:

O people! I am God's appointed authority in His earth (sulțān Allāh fì ardihi), and I rule with His divine help and endorsement. I am guardian of His property and I act in accordance with His will and what I give, I do so by His permission.

The Egyptian scholar 'Abd al-Hamīd al-Mutawallī has commented that most people had taken this statement from the literary work of an Andalusian author who was not a jurist and the quotation was also less than accurate. ${ }^{48} \mathrm{Al}$-Qaraḍāwī concurred and added: even if al-Manșūr's statement were accurate, it is best to treat it as an isolated incident. "We are not bound by al-Manșūr's precedent on this." Al-Qaraḍāwī then recounts an incident where al-Manșūr had issued an order to the then judge of Basra, Sawwār b. 'Abd-Allāh, in a land dispute between a merchant and an army commander - that the land should be given to the latter. The judge wrote back to say "the evidence I have before me shows that the land belongs to the merchant". The caliph wrote again: "You shall give it to the army commander." And when the judge retorted repeating his earlier message, al-Manșūr conceded and even praised God for the firm stand the judge had taken in the cause of justice. Al-Qaraḍāwī further recounted two other cases to show that al-Mansur did not see himself as someone above the law and he was in fact a learned man who knew the limits of his authority vis-à-vis the $\operatorname{sharì~}^{-} a h$. Is it credible then to hear the same caliph arrogating divine authority 
to himself? Claims of theocratic rule are thus unacceptable and Islamic thought hardly leaves the matter open to doubt. ${ }^{49}$

\section{Whether Iran is a theocracy}

Commentators who characterised the Islamic Republic of Iran as a theocratic state have also noted that Iran itself has made no claim to theocracy. Ayatollah Khomeini's theory of the guardianship of the jurist (Arab. wilāyat al-faqī ; Pers. velāyat-e faqīh) and his own religious personality evidently lent support to the current theocratic image of Iran. But Iran, under President Khatami, became a keen supporter of civil society, civilian rule, and people's rights.

Al-Qaradāin̄ who addressed this issue in his 1997 publication maintained that the impression of a theocratic state was less than accurate. The leading offices of state in Iran, including those of the President, the Supreme Leader, and the Iranian Parliament (the Majlis) were all elective. Ministers and government officials did not cease to be taken to task by the Majlis. On one occasion, in 1984, for instance, the Majlis removed no less than seven ministers by a vote of no-confidence in accordance with the constitution. ${ }^{50}$

Whereas the Sunnites maintain that caliphate and government are elective and civilian, the Shi ites consider the Imāmate as part of their theology wherein the Imām receives his title through hereditary succession from the Prophet. The Imām is thus a theocratic figure who is also held to be infallible and removed from the ability to err and to commit sin (ma sșum).$^{51}$ Notwithstanding this, however, Shi' ite clerics and commentators have maintained that "government as a time and place-bound phenomenon is human and has a worldly origin". No one can thus claim to be representing God or the Prophet in the exercise of political power [...]. Government and the exercise of political power thus fall into the realm of people's voluntary and chosen acts, and essentially cannot be otherwise." ${ }^{{ }_{52}}$

Twelver Shi ites believe their last Imām - Muhammad b. al-Hasan al-Mahdī, who was born in 869 , over a thousand years ago! - to be still alive, albeit in a state of 'occultation' (ghaybah). ${ }^{53}$ As Marcinkowski ${ }^{54}$ writes:

$[\mathrm{H}] \mathrm{e}$ is believed to have been hidden by God from his enemies by entering into subsequent kinds of 'occultation' or 'concealment' (ghaybah). ${ }^{55}$ The first of them is referred to as 'minor occultation' during which he is said to have communicated with the faithful only through his representatives who alone knew about his whereabouts. ${ }^{56} \mathrm{After}$ several years, he is believed to have entered into a 'major occultation' that is supposed to have taken place in either 939 or 941 (depending on the sources). During this 'major occultation', which is believed to continue until this very day, he is not accessible to anyone ${ }^{57}$ The main contention against this made by Sunnites is that it would be against the laws of nature that he is still alive - after more than 1,000 years in concealment. Shi ites used 
to counter by stating that some of the prophets mentioned in the Qur'ān, too - such as Jesus Christ and Elijah -, are considered to be still alive by all Muslims. ${ }^{58}$

Twelver Shi ites also believe that the mantle of Imāmate was ever since carried by his general deputies (sing. $n \bar{a}$ ' $i b-i$ Imām) who led the Shi ite community but who were not infallible. In the absence of Prophet and Imām, the affairs of state are determined in accordance with the will and consent of the community through consultation. This comes close to the Sunnite doctrine of khiläfah, a position reflected in the views of the late President of the Shi ite Supreme Council of Lebanon, Muhammad Mahdī Shams al-Dīn (d. 2001) as discussed below. ${ }^{59}$ Furthermore, government in both the Sunnite and Shi ite doctrines is a contract which gives rise to mutual rights and obligations. The fourth caliph 'Alī b. Abī Țālib (r. 656-661), has explicitly referred to these rights and obligations in Sermon 207 of Nahj al-balāghah. Political leaders are consequently bound, under both doctrines, to conduct government affairs through consultation with the community. ${ }^{60}$ Some of the leading Iranian clerics, including Muhammad Kāẓim Khurasān̄̄ (d. 1911), issued fatwās during the period of the Iranian Constitutional Revolution (1905-11) to say that "It is a [Shi ite] religious requirement that during the Era of Absence [ghaybah] the government of the Muslims rests with the majority of the people." ${ }^{\prime 61}$

Ayatollah Khomeini's (d. 1989) idea of 'Guardianship of the Jurist' (wilāyat $a l$-faqīh) entrusted the leading jurist to assume leadership and act as a Deputy ( $n \bar{a}$ ' $i b)$ of the Imām. Khomeini's notion effectively adjusted the Shi 'ite doctrine which had postponed the establishment of an Islamic state until the return of the last Imām. Wilāyat al-faqīh thus enabled the jurist to establish an Islamic government during the Imām's absence, and Shams al-Dīn's concept of people's authority (wilāyat al-ummah) transferred the authority from the jurist back to the wider community, thus constructing a common doctrinal position on Islamic government among all Muslims. ${ }^{62}$ But the question of the 'Hidden Imām' still remained problematic.

Muhammad Mahdī Shams al-Dīn's concept of wilāyat al-ummah restored to the community itself the authority which Khomeini had entrusted in the leading jurist. Shams al-Dīn explained that following the Prophet's demise, the ummah became the locus of political authority, according to the Ash 'arites and the Sunnites, but only the Imām had title to leadership, according to the Shi ite doctrine. 'Alī b. Abī Țālib was the first Imām to inherit that authority and the succeeding Imāms carried the title after him. The Twelfth Imām has remained absent, in which case the umma assumes his authority during his absence, and the ummah exercises it through elective and consultative methods. ${ }^{63}$

Salīm al- 'Awwā and Tawfīq al-Shāwī regarded Shams al-Dīn's wilāyat al-ummah as a logical extension of Khomeini's doctrine of velāyat-e faqīh, which was basically an elective office; the Sunnis only differed with it in that they did not stipulate that 
the candidate must be a faqīh. Shams al-Dīn effectively restored that choice back to the community. ${ }^{64}$

Islam advocates, not a theocracy, but a people's government. Note also that at no time has the Iranian state arrogated divinity to itself due to the absence of a living Imām. Iran has in fact a more consistent record of democratic governance compared to many other Muslim countries. In sum, neither the Shi ite doctrine nor the post revolutionary experience of Iran provide an argument by which to characterise the Islamic state as a theocracy, even among the Shi ite community, let alone the wider majority of Sunnites.

\section{A 'qualified democracy'?}

Democracy is predicated in a set of principles most important among which are a recognition of the inherent worth of every human being, a representative and participatory government, acceptance of the rule of law, equality of all citizens before the law, and a high level of tolerance of unconventional views and beliefs. Islam contains a set of principles which "make it highly responsive towards many of the moral and legal prerequisites of democracy" ${ }^{65}$ If democracy means a system of government that is the opposite of dictatorship, Islam is compatible with democracy "because there is no place in it for arbitrary rule by one man or a group of men" ${ }^{66}$ A whole generation of Muslim scholars have tried to redefine concepts such as bay 'ah, shürā and $i j m \bar{a}$ ' in ways that may deviate from their traditional usage, but they are "no more removed from their original meanings than modern European models of democracy are from the ancient Greek demes" ${ }^{67}$

Among the differences commentators have noted in comparing democracy to an Islamic system of rule, one is the attribution of sovereignty to God in Islam, but to the people in a democratic state. In a democracy the people may bring any legal order or system they wish for themselves whereas an Islamic government is bound by implementing the shari ' $a h$. Furthermore, democratic aims are generally material aims whereas Islam seeks both material and spiritual values. Democracy may not regulate personal morality whereas this too is of concern to an Islamic order. ${ }^{68}$

Taha Husayn (d. 1973), one of the most influential twentieth-century Egyptian writers and intellectuals and a figurehead for the modernist movement in Egypt, observed that the political system in early Islam was neither democratic nor did it rest on absolutism as understood by the Greeks and Romans; it was a purely Arab system of government to which Islam added its own requirements. Muhammad Husayn Haykal (d. 1956), the Egyptian writer, journalist, politician and former Minister of Education, who penned also a biography of the Prophet, noted that the system of shürā in early Islam did not constitute a check on the powers of the caliph. Even though the caliph had to consult the community, he was not answerable to it. ${ }^{69}$ The contemporary scholar Dịāa al-Dīn al-Rīs has responded with some reservations. First, 
if by 'purely Arab' it is suggested that the Islamic state is ethnocentric, then it must be said that Islam does not advocate ethnicity at all. Second, to say that the Islamic state was not democratic also does not reflect the fact that the people's consent, homage and welfare lay at the foundation of the state of Medina. The commitment of that state to justice, equality and people's rights also went a long way toward democracy as a government of the people, by the people, for the people. Al-Rīs adds, however, that while the Islamic system subscribed to these principles, it was not identical with democracy. The will of the people is sovereign in a democracy but in Islam the sharī'ah, although generally supportive of it, also introduces limitations to it. In a western democracy, the people's sovereignty admits no limitation whereas in an Islamic system the qur'ānic injunctions on equality and justice may not be violated in the name of people's sovereignty. Al-Rīs concludes that Islamic governance and democracy have aspects in common just as they also differ in certain respects. It is in this way sui generis as it has characteristics of its own. ${ }^{70}$

In Ḥassan al-Ṭurābī's assessment, an Islamic government is not exactly a direct government of the people by the people: it is rather a government of the shari ${ }^{-} a h$. But in "a substantial sense, it is a popular government since the shari' ah approves the convictions of the people and, therefore, their direct will". ${ }^{71}$

Al- 'Awwā is critical of the view some jurists have taken that consultation (shūrā) was only recommended and not an obligatory requirement. This is indefensible in view of the qur'ānic command (3:159) addressing the Prophet to consult the community, and also the Prophet's own practice of frequent recourse to shūrā, followed by the precedent of the Pious Caliphs and the Companions after him. Thus "I find it strange to see that some have considered shūrā only advisable but not obligatory." 72 Al- 'Awwā then cites al-Qurțub̄i in support of the position that shürā is one of the cardinal principles of Islamic government and an obligation to be implemented. ${ }^{73}$

Islamic government is a qualified democracy in that it holds the community as the locus of authority that can take the government to account and may ultimately depose it. The sharī'ah also vests the people's representatives with the authority to pass consensus-based legislation through $i j m \bar{a}{ }^{\prime}{ }^{74}$ This is the basic premise of a minority view among Muslim scholars that sovereignty in the Islamic polity belongs to the ummah. Others have qualified this to say that the ummah is vested with "executive sovereignty (al-sultān al-tanfidh $\vec{\imath})$ ". ${ }^{75}$ Still others maintain that the state exercises a composite sovereignty (al-siyādah al-muzdāwijah) of the ummah and the sharī' $a h$, which are intertwined and cannot be meaningfully separated. ${ }^{76}$

According to a legal maxim of the sharl' 'ah earlier quoted, it is the people's welfare on which the success and failure of an Islamic government is to be judged. A government that makes decisions independently of people's welfare thus deviates from its basic terms of reference. ${ }^{77}$ This may explain why al-Qaraḍāwī characterises 
the state in Islam as "a state of rights and liberties (dawlat al-huqūq wa 'l-hurriyyāt) which is committed to protection of the rights of life, ownership, personal security and honour, and right to basic necessities. These are the essential values ( $a l$ darūriyyāt) which the sharī'ah seeks to protect." ${ }^{\prime 78}$ Muhammad Asad observed that a state may be described 'Islamic' if it incorporates in its constitution the clear and unambiguous ordinances of Islam which have a direct bearing on the community's socio-political and economic life. ${ }^{79}$

Al-Qaraḍāwī has also spoken forcefully against the detractors of democracy in the name of Islam, "for Islam advocates the people's government $[\ldots]$ and there is essential harmony between Islam and democracy". Islam has resolutely denounced oppressive and arrogant rulers, the Pharaoh and the Kora, who sought to enslave and humiliate their people. The Prophet expressed this vividly in a hadith: "When you see my community afraid of calling a tyrant 'tyrant' then take leave of it." The ruler in Islam is "agent and employee of the community" who is accountable to it. This was amply shown in the statements of both the first and second caliphs, Abū Bakr and 'Umar (d. 634 and 644, respectively). Al-Qaraḍāwī adds that democracy is the fruit of a long-standing struggle in which the people successfully subjugated despotism. It is humanity's shared achievement and "we are entitled [...] to take from others ideas and methods that benefit us and do not, in the meantime, clash with a clear and unequivocal text". ${ }^{80}$ Election according to al-Qaraḍāwī, and many others, is a form of testimony (shahādah) by which the electorate testifies to the suitability of the candidate. The electorate is under an obligation to give testimony and "discharge his electoral duty" to ensure only the strong and trustworthy are elected. ${ }^{81}$

The Shi ite doctrine concurs with its Sunni counterpart to say that Islam and democracy are compatible. Hasan Yousefi Eshkevari (b. 1950) is even more emphatic in saying that despotism, authoritarianism and, more specifically, ruling people without their consent are in contradiction with the essence of religion, human free will, and Islamic texts and guidelines. ${ }^{82}$ "In our view," Eshkevari observed, "in the present state of the world, the democratic method is the most religiously correct way of social administration for Muslims." If the ideal of religion is to uphold truth and justice and the ideal of democracy is to do the same based on people's will and consent, then without doubt democracy is the most suitable method for implementation of justice. ${ }^{83}$

Political parties are an important feature of modern democracy. On this too, al-Qaraḍāwī dismisses the argument that Islam rejects political parties. The sharī ah principles of hisbah (promotion of good and prevention of evil), and nașịhah (sincere advice) as well as the people's right to criticise their government leaders can be given a meaningful role within a multi-party system. Political parties are therefore acceptable in an Islamic system. To curb oppressive rule is normally not within the capacity of individuals acting in isolation. But when they join together in large 
numbers, they can influence government policy, in which case there should be no need for acts of rebellion and uprising against oppressive rulers as often happened in the past. ${ }^{84}$

In its broad outline, the sharī 'ah also supports the people. It was due probably to its strong advocacy of people's rights that totalitarian regimes of the past had difficulty in the implementation of sharì'ah. The 'ulamä' have acted, more often than not, as protectors of the people's rights and resisted oppressive rule.

Ameer Ali (d. 1929) commented that the shari 'ah gave the people a code which consecrated the principle of self-rule, made men equal in the eyes of the law, and made the government subordinate to the law. An examination of the precedent of the early caliphs depicts a popular government administered by an elective chief with limited powers. At a time of history when everywhere "the masses were in hopeless subjugation, Islam elaborated a political system fundamentally republican in character, stressing the duties of the sovereign towards their subjects, and the freedom and equality of people". ${ }^{85}$

Muhammad Iqbal (d. 1938) spoke affirmatively of the democratic impulse of Islam but said that the Muslims did not effectively develop the elective principle. This was due partly to the Persians and the Mongols, the two great races which embraced Islam and formed governments; they were not only strangers to the elective principle, but actively opposed to it. The Persians worshipped their monarchs as manifestations of divine power, whereas the Mongols were given to tribalist methods. ${ }^{86}$ Iqbal added: "The republican form of government is not only thoroughly consistent with the spirit of Islam, but has also become a necessity in view of the new forces that are set free in the world of Islam." The position of the ruler in the eyes of the shari 'ah is the same as that of an ordinary Muslim. The basis of legislation, after the clear injunctions of the shari 'ah, is the agreement of the Muslim community ${ }^{87}$ Iqbal's commentator, Khalifa Abdul Hakim, characterised "Iqbal's conception of Islamic democracy" as closely aligned with what Islam experienced during its early period. In this "there was no ruling class, freedom reigned everywhere. The state was a welfare state." The rulers were elected on the merit of their moral and intellectual excellence. ${ }^{88}$

Muhammad Asad (d. 1992) described the Islamic government as democratic and noted that democracy, as conceived by the West, was infinitely nearer to the Islamic system than to its Greek parallel. For Islam maintains that all human beings are equal and must be given the same opportunities for development and self-expression. Islam essentially envisaged an elective government. A government that comes to power by "non-elective means becomes automatically illegal". 89

The evidence I have examined suggests obviously that there are some differences between the Islamic system of rule and a modern democratic state. Yet there is enough 
in common between them to justify the characterisation of Islamic government as a qualified democracy.

\section{Separation of Powers}

If the historical caliphate is taken as a basis of assessment, then it would appear that separation of powers does not find a place in an Islamic polity. Many commentators have thus held that separation of powers is alien to Islamic political thought. There is a basis for this opinion as I shall explain, although I believe that this conclusion is less than accurate and calls for a review.

The historical caliphate subscribed to administrative centralism and concentration of powers under the combined effect of wiläyah (public authority) and wakālah (representation). The caliph in his capacity as wakil and representative of the community was accordingly vested with political authority by the community. He delegated in turn his powers to other government office holders, ministers, governors, judges, etc., who are entrusted with delegated authority which they exercise on the caliph's behalf. With the exception of the judges whose position in respect of enforcing the shari 'ah is parallel to that of the caliph himself, all other officials act, in effect, as delegates and assistants to the head of state. ${ }^{90}$

A unitarian approach to governance is also the conclusion often drawn from the Islamic doctrine of Divine Oneness (tawhīd) which has deeply impacted Islamic religious and political thought. Thus it is understood that Islam takes a holistic and unitarian approach to governance and it is averse therefore to the notion of separation of powers. Such was deemed to bear greater harmony with the integrationist outlook of tawhìd and territorial unity of the caliphate. This was also seen to be in line with the precedent of the Prophet-cum-head of state and the Rightly-Guided caliphs after him who acted as the repositories of political power. This unitarian approach also seems to be manifested in the postulate that Islam does not admit of separation between religion and state. This is evidently very different from the western nation-state model that bore the philosophical vestiges of Enlightenment, which separates religion from politics and regards religion as a concern only of personal conscience of the individual. Under the Islamic caliphate model, the state is deemed as the patron and protector of religion, and under mandate also to implement the sharī $a h$. Hence an organic unity, not separation, between religion and state is suggested.

The theoretical blueprint of caliphate visualised two categories of government officials, those who exercised political authority, or hukm, and those who only acted in the capacity of assistants (mu'äwinūn) to the head of state. The leading officers were in turn assisted by deputies and assistants who acted as administrative officers but did not partake in the exercise of hukm. In his capacity as the centre of political 
and executive authority that originated in the community's pledge of allegiance (bay ' $a$ h) and representation, the head of state acted on behalf of the community but remained accountable to it. Hence the caliphate model did not recognise autonomous individuals and organs in the government hierarchy; everyone exercised delegated authority that emanated from the office of the head of state. ${ }^{91}$

Muslim commentators are reluctant, however, to extend the implications of this administrative centralism to anything more than an organisational approach that need not interfere with the essence of accountability, nor of a functional separation of powers in the various organs of state. The head of state - although the supreme political figure - could not be an absolute ruler, for he is subjected to the overarching authority of the ummah and that of the shari $a h .{ }^{92}$

It would appear upon scrutiny that the centralised pattern of administration originated in a derivative logic and a persuasive precedent, which were taken up and subsequently reflected, somewhat unquestioningly perhaps, in the juristic works of the 'ulama'. The unity (wahdah) of government in the territorial domain of the historical caliphate was reflected, as al-Sanhūrī observed, in a unified central authority (sultah markaziyyah islämiyyah) which was personified by the caliph. ${ }^{93}$ Al-Sanhūrī added, however, that a centralised state was not an inflexible rule and the historical pattern may be changed in the light of prevailing conditions. There is nothing in the sources of the shari 'ah to impose a mandate in regards to the administrative structure of government. ${ }^{94}$ Speaking of the legislative function of the Islamic system and its independence from the executive, Wahbah al-Zuhayli similarly went on record to compare the Islamic system with its western counterpart and say that both

[v]alidate the principle of separation of powers. For legislation in Islam emanates from the Qur'ān and sunnah, consensus (ijmā ') of the ummah, and ijtihād. All of these are independent of the Imām, nay but he is bound by them and by the conclusions drawn from them. The principle of $i j m a \bar{a}$ ' in Islam manifests the will of the people [...]. Both [democracies] reject despotism and consider the people as the locus of authority in political and government affairs. ${ }^{95}$

The head of state has thus little control over legislation in an Islamic polity. The whole structure of law-making in the Islamic jurisprudential theory is controlled by lay jurists and mujtahids who act independently of the head of state.

As for the judiciary, here too the 'ulamā' dominated the judicial branch as judges were traditionally selected from among those learned in the shari 'ah. Since the shari ' $a h$ was not enacted by the state, and the state had in effect only an administrative role with regard to it, the 'ulamä' and judges regarded themselves as custodians of the shari 'ah almost independently of the state hierarchy. 
Zaydān thus wrote categorically: "No one whatsoever is permitted to interfere in the work of the Muslim judge or $q \bar{a} d \bar{l} \bar{l}$ with a view to influence him away from the course of justice. Anyone who violates this guideline is violating the sharī ah." ${ }^{\prime \prime 6}$ This is because the duty to administer justice, although primarily borne by the head of state, with the judge acting as his deputy, the latter shares that function with him by virtue of a direct sharī'ah mandate. Furthermore, in his task to administer the shari ${ }^{-} a h$, the judge basically plays a declaratory role. He ascertains the ruling of the shari ' $a h$ and declares its application to a dispute before him. The judge does not, in other words, create a ruling $(\mathrm{hukm})$ in the absence of evidence in the shari ' $a h$. Then for a judge to fulfil that role, he must act independently of extraneous influences; for he alone is accountable for any error or miscarriage of justice. He is within his rights also to reject all interference, even from the head of state, in the conduct of his duty. ${ }^{97}$

In the present writer's opinion, the implications of tawhì need not be extended to the organisational structure of power in the state. One can believe in One God without necessarily extending this to the structure of state hierarchy. The centralist model would appear to have taken hold in the early years of the advent of Islam when the nascent state of Medina found itself in continuous warfare with the pagans of Mecca. A rapid pace of territorial expansion in the succeeding decades also extended the geographical domain of Islam far beyond the Arabia peninsula and brought it in close contact with other cultural traditions. Administrative centralism was thus most likely seen to be in keeping with the objective of political unity of the state, a position that may have in turn influenced Muslim jurists and commentators to advocate a centralist model. Furthermore, if a centralist model is deemed to be congenial to the territorial unity of the state, that logic would still fail to sustain the view that internal separation of powers would necessarily jeopardise political unity.

The matter thus remains open to considerations of public interest and consultation (mașlahah and $s h \bar{u} r \bar{a})$. It is through these methods that necessary adaptation and adjustment in the administrative structure of the state could be devised and implemented.

\section{Freedom of Religion and Religious Pluralism}

Historical accounts indicate that Muslims have maintained a track record of peaceful coexistence with other religious communities in their midst. Starting with accounts of the Prophet Muhammad's engagement with the Jews and Christians of Medina and recognition of their freedom of religion, as documented in the renowned 'Constitution of Medina', peaceful coexistence is also endorsed by many of his sayings and hadīths. This pattern continued during the dynastic periods of the Umayyad, Abbasid, Ottoman, and Mogul empires where people of different 
religions, race and language lived as neighbours and compatriots. The overall picture is one of recognition and mutual respect, notwithstanding isolated incidents and episodes to the contrary. Islam recognises religious pluralism in its postures with other religions, as I shall presently elaborate. It is also internally pluralistic in its recognition of diversity of thought and doctrine among its various schools and sects from the Shi 'ite and Sunnite to the Hanafì, Shāfi ' $\overline{1}$, Mālikī and Hanbalī schools that are prevalent throughout the Muslim world to this day.

Numerous passages in the Qur'ān advocate freedom of religion:

Let there be no compulsion in religion. (2:256)

Whoever wishes to believe, let him believe, and whoever wishes to disbelieve, let him disbelieve. (18:29)

The Qur'ān also provides in an address to the Prophet Muhammad:

If God had willed everyone on the face of the earth would have been believers. Are you then compelling the people to become believers? (10:99; see also 11:18)

The question in this last verse begs the reply that God the Most High has Himself willed that people should be free to decide for themselves; and that no one should try to change that. Religious pluralism has no uniform definition and is seen differently by different commentators. But if one takes the more simplified characterisation of religious pluralism, then religious pluralism would mean that "different religions co-exist within the same society". ${ }^{98}$ In that sense, Islam too is certainly pluralist, because, as some might argue, "no civilisation in history has demonstrated a more resolute commitment to pluralism than Islam”. For not only the Qur'ān itself but also the 'Constitution of Medina' and the acts and deeds of the Prophet himself attest to Islam's affirmative stance on pluralism. ${ }^{99}$ Space does not permit a detailed enquiry, which I have attempted elsewhere. Here it will suffice to outline the basic qur'ānic evidence: ${ }^{100}$

He it is Who created you; some from among you are disbelievers and some of you are believers. (64:2)

This is a clear affirmation that people are bound to differ in respect of the religion they wish to follow. To quote the Qur'ān on religious pluralism:

Say: We have faith in God, and in that which has been sent down to Abraham, Ishmael, Isaac and Jacob and the tribes, and in that which was given to Moses and Jesus, and in that which was given to all the prophets from the Lord. We do not make any distinction between any of them and to Him do we submit. (2:136)

For each of you We have appointed a right way and an open road. (5:48) 
Pluralism in the qur'ānic language is more than a mere superficial acknowledgement of the religious:

Verily, those who believe and those who are Jews, and the Sabeans and the Christians, all those who believe in God and the last day and do righteous deeds, they shall have their recompense with God. They shall not fear nor shall they sorrow. (2:62; also 5:69)

While speaking of freedom of religion as a qur'ānic mandate, al-Qaraḍāwī observes that anyone who violates this freedom and compels people into embracing any religion commits an act of fitnah (sedition) that must be avoided. ${ }^{101}$ Islam's commitment to freedom of religion and religious pluralism was put to the test at a time when the Prophet was still in Mecca. A group of the Meccan pagans proposed to the Prophet that they would be prepared to worship Allah for a year if he would also reciprocate by worshiping their deities; in this way both sides would gain insight into each other's religions. A short qur'ānic sūrah was then revealed ordering the Prophet to tell the unbelievers: "I do not worship those that you worship, nor do you worship He Whom I worship [...]. To you is your religion, and to me, my religion" ( $Q$, sura 109). This is a clear acceptance of religious pluralism in Islam.

The universality of the qur'ānic message is often suppressed, however, by some of the orthodox exegetes who diluted the essence of religious freedom in the Qur'ān through doubtful interpretations, especially of these two verses: "Verily the religion with God is Islam - inna al-dīn 'ind Allāh al-Islām" (3:19); and "Who seeks other than Islam as a religion, it will not be accepted from him - wa man yabtaghi ghayr al-Isläm dìnan fa-lan yuqbal minhu" (3:85). These are often cited as incontrovertible evidence that only those who follow Islam shall be saved.

Here we note that Islām has two meanings, one which names the religion revealed to the Prophet Muhammad. But Islām (lit. 'submission') is also the primal religion of submission preached by Adam to all his posterity, who accepted God as their Lord, as in the divine invocation: alastu bi-rabbikum? Qālū balā shahidnā (Am I not your Lord? They said: Yes, we do testify; 7:172). All humankind then, before time began, professed Isläm in its widest sense of submission. Understood in this way the two verses (3:19 and 385) recognise the validity of every religion that entails submission to the divine will.

The essence of submission as a common denominator of all religions is featured frequently in the Qur'ān: "And We have sent to every people a messenger that they may worship God" (16:32); and (10:47): "And for every people there is a messenger. When their messenger comes, they are judged with equity and are not wronged." But instead of taking these verses as affirmation of the validity of all religions prior to Islam, they are presented as declarations in support of Islam's finality that override and abrogate other religions. The universalist verses of the Qur'ān are thus rarely allowed to stand alone as the unencumbered words of God. ${ }^{102}$ 
The spirit of openness and religious pluralism in Islam has also been constrained by the demands of nationalism and the Muslim world's post-colonial experience in constitution making. Constitutions after constitutions were introduced by the countries of Middle East and Asia, which singled out Islam as the state religion, while some also declared Islamic law as the basic source of legislation. This experience is still with us and is not likely to change in the foreseeable future. Notwithstanding the guarantee of freedom of religion to non-Muslims under these constitutions, their clauses on state religion could be said to be ahistorical, and a response to colonialist aggression that impinged on the self-identity of Muslims.

Prior to the era of constitutionalism, which is of western origin, scholastic teachings and praxis in Muslim lands aimed at upholding religious symbols and observances (al-sha 'a' 'ir), such as the call to prayers (adhān) in public mosques, Friday congregational prayers, and also closure of restaurants in Muslim residential areas during Ramadan. The imām would also recite, toward the end of his Friday sermon, the name of the head of state and invoke God's protection for him and the Muslim community. One can perhaps envisage the possibility of taking these rather than formal constitutional declarations on state religion as the index of Islamic identity of states in highly pluralistic Muslim societies - if this would indeed serve the desired purpose of genuine religious pluralism within the given conditions of each country.

\section{Conclusion and Recommendations}

To conclude, Islamic government may be said to be profoundly committed to justice, people's welfare and the rule of law. It is a government that aspires to people's trust and exhibits a high level of receptivity to their legitimate wishes.

Contemporary writings on the nature and composition of an Islamic polity are generally cognisant of the absence of a particular model or prototype for an Islamic state and lay emphasis instead on conformity to a set of principles. Therefore:

- A state may consequently take a variety offorms, and be internally organised in different ways, yet qualify as Islamic if it complies with those principles. Salient among these are consultation, freedom, equality and justice, commitment to the rule of law and to people's welfare. Government power in an Islamic polity is also limited by virtue of its commitment to the implementation of the sharī'ah. An Islamic government bears essential harmony with democracy and its concomitant principles of accountability, commitment to basic rights and liberties, and a system of checks and balances that curb arbitrariness and abuse. Islam advocates a participatory and civilian system of rule and 
its powers are limited by reference to the shari ' $a h$ and accountability to the people.

- Aformal constitution is acceptable in an Islamic polity if it serves to articulate these principles and the modalities of their implementation. Any government that is committed to these principles, defends the country against aggression and inspires people's trust qualifies as Islamic. It may be similar to the historical caliphate or may be different and combine new features in response to its own particular requirements. ${ }^{103}$

Emerging democracies and Muslim jurisdictions in Southeast Asia do perhaps fare better on accountability and the rule of law compared with many of their counterparts elsewhere in Asia and Africa. On a broader note, however, Muslim countries have not been all that successful in making constitutionalism and democracy a reality in their governments. The general picture one has is rather a poor record of achievement on commitment to democratic principles. Many present-day Muslim countries have impressive constitutions but tend to be falling short on implementation. Therefore:

- Accountability and good governance are not simply a question of having a constitution but more importantly of an unwavering commitment to good practice.

- A similar picture obtains unfortunately with regard to a gap which exists between the theory and practice of freedom of religion and pluralism - and what it takes to translate these into reality. In this regard, it may be said that the normative teachings of Qur' 'an and Sunnah are more supportive of freedom of religion and pluralism than scholastic interpretations of the schools and scholars of the sharī'ah.

- The evidence reviewed in this essay shows Islam's substantive harmony with the principles of democracy, yet it is felt that Muslim scholars and 'ulamā' have not been sufficiently expressive of this. This aspect of harmony between the Islamic and modern laws merits, in the present writer's opinion, greater exposure and recognition simply because of the common misperceptions that prevail purporting Islam to be opposed to democracy. A case can therefore be made that Muslim scholars and experts in the field should address the gap that currently exists between the negative yet commonly held perceptions of Islam on religious freedom. Islam is affirmative on religious and intellectual pluralism as our review of the source evidence has shown.

- Our analysis also shows substantive support in the theory and praxis of Islam for the democratic principle of separation of powers. If this is deemed to offer a better prospect for accountability and healthy checks and balances in the exercise of power, then separation of powers merits recognition and support 
from the Islamic viewpoint. An acknowledgement of this aspect of the Islamic teachings may also help to improve the prospects of a more refined approach to separation of powers in Muslim countries and their respective constitutions.

\section{Notes}

1. Cf., Frank I. Michelman, Brennan and Democracy (Princeton: Princeton University Press, 1999), 5-6.

2. Lawrence H. Tribe, American Constitutional Law (New York: Foundation Press, 2000, 3rd ed.), 20.

3. Ronald Dworkin, Taking Rights Seriously (Cambridge MA: Harvard University Press, 1978), 133.

4. Zeid al-Ali, "Iraq: A Constitution or an Epitaph?", OpenDemocracy, 15 August 2005, available online at http://www.opendemocracy.net/conflict-iraq/constitution_2757.jsp (accessed on 15 February 2010).

5. Cf. L.B. Deng, "The Sudan Comprehensive Peace Agreement: Will It Be Sustained?", Civil Wars 7, no. 3 (2005), 244.

6. Cf., Samuel Issacharoff, "Constitutionalising Democracy in Fractures Societies", Texas Law Review 82 (2004), 1861.

7. Fareed Zakaria, "The Rise of Illiberal Democracy", Foreign Affairs 76 (November 1997), 35; Edward J. Mansfield and Jack Snyder, "Prone to Violence: The Paradox of the Democratic Peace", National Interest 82 (Winter 2005-06), 39-45.

8. Larry Diamond, Developing Democracy: Towards Consolidation (Baltimore: Johns Hopkins University Press), 199.

9. The ruler's duty to consult the community - clearly stated in Qur'ān 3:156 and 42:36 and also manifested in the precedent and Sunnah of the Prophet Muhammad - was ignored and subjected to the vagaries of power politics under the founder of the Umayyad dynasty, Mu'āwiyah b. Abī Sufyān (r. 661-680) and his son and successor, the notorious Yazīd (r. 680-683).

10. Bay 'ah is an act by which individual A informs individual B that A supports B's assumption of the leadership position in question and gives $\mathrm{B}$ his or her allegiance.

11. 'Abd al-Razzāq al-Sanhūrī, Fiqh al-khilāfah wa tatawwuruhā, Arab. trans. and comm. Nadia al-Sanhūrī and Tawfīq al-Shāwī (Cairo: al-Hay'ah al-Mișriyyah al- 'Āmmah li 'l-Kitāb, 1989), 62-4; 'Abd al-Ḥamīd Mutawallī, al-Sharī'ah al-islāmiyyah ka-mașdar asasī li 'l-dustūr (Alexandria: Mu'assasah Shabāb al-Jāmi' ah, 1990, 3rd ed.), 214.

12. Ḥasan al-Turābī, Tajdìd uṣūl al-fiqh al-islāmī (Jeddah: Dār al-Sa ūdiyyah li 'l-Nashr, 1404AH/1984), 20.

13. Lecture series by Shaykh Ahmad Huraydī held at the University of Cairo - as quoted by Fu'ād A. Aḥmad, Ușūl niz̄ām al-ḥukm fì 'l-islām, 15-16.

14. Ja far al-Subḥānī, Ma ālim al-ḥukūmah al-islāmiyyah, lecture series compiled by Ja far al-Hādī (Beirut: Dār al-Adwā', 1405AH/1984), 76-7.

15. P.J. Vatikiotis, "Islamic Resurgence: A Critical Review", in: Alexander S. Cudsi and Ali E. Hillal Dessouki (eds), Islam and Power (Baltimore and London: John Hopkins University Press, 1981), 193 and 196.

16. Muḥammad Salīm al- 'Awwā, al-Fiqh al-islāmī fì țarīq al-tajdīd (Beirut: al-Maktab al-Islāmī, 1419 AH/1998, 2nd ed.), 44.

17. Tawfīq al-Shāwī, al-Mawșū 'ah al- 'așriyyah fì 'l-fiqh al-jinā'ì al-islāmī (Cairo: Dār al-Shurūq, 1421AH/2001), 1:106.

18. Muhammad b. Jarīr al-Ṭabarī, Tafsīr al-Ṭabarī (Cairo: Dār al-Ma rifah, 1374AH/1995), 5:87; also quoted in Muhammad Ḍiyā' al-Dīn al-Rīs, al-Nazariyyāt al-siyāsiyyah al-islāmiyyah (Cairo: Dār al-Ma ārif, 1967), 326 n. 20. 
19. Abū 'Abd-Allāh Muhammad b. Aḥmad al-Qurțubī, al-Jāmi' 'li-ahkām al-Qur'ān (Cairo: Dār al-Kutub al-'Arabiyyah, 1387AH/1967, 3rd ed.), 5:255.

20. Muhammad b. Ismā̄îl al-Bukhārī, Șahīh al-Bukhārī, Eng. tr. Muhammad Muhsin Khan (Lahore: Kazi Publications, 1979), vol. 9, hadìth no. 252.

21. Ismā'īl a-Badawī, Tawliyah ra'īs al-dawlah fì 'l-sharī'ah (Cairo: Dār al-Fikr al- 'Arabī, 1986), 220.

22. Taqī al-Dīn Ibn Taymiyyah, al-Siyāsah al-shar 'iyya fì iṣlāh al-ra'y wa 'l-ra'iyyah (Cairo: Dār al-Kitāb al- 'Arabī, 1951, 2nd ed.), 18.

23. Ibid., 43.

24. Cf. Mohammad Hashim Kamali, "Characteristics of the Islamic State", Islamic Studies 32 (1993), 24; Anwar Ahmad Qadri, Islamic Jurisprudence in the Modern World (Lahore: Ashraf Press, 1981, 2nd ed.), 270.

25. Fathị̄ 'Uthmān, al-Fikr al-qānūnī al-islāmī (Cairo: Mațba ah Mukhaymar, n.d.), 119; Bāqir Sharīf al-Qurshī, Nizāām al-ḥukm wa 'l-idārah fì 'l-Islām (Najaf: Mațba ah al-Ādāb, 1386AH/1966), 27.

26. 'Abd-Allāh Khațịb al-Tabrīzī, Mishkāt al-mașābīḥ, ed. Muhammad Nāṣir al-Dīn al-Albānī (Beirut: al-Maktab al-Islāmī, 1399AH/1979, 2nd ed.).

27. Cf. Kamali, "Characteristics", 32 n. 29; al-Shāwī, al-Mawșū 'ah, 2:286; Muștafā Kamāl Wașfī, al-Nizāam al-dustūrī fì 'l-Islām muqarinan bi 'l-nuzūm al- 'aṣriyyah (Cairo: Maktabah Wahbah, 1414AH/1994, 2nd ed,), 14-15; Yūsuf al-Qaraḍāwī, Min fiqh al-dawlah fì 'l-Islām (Cairo: Dār al-Shurūq, 1417AH/1997), 58; Manzuruddin Ahmed, "The Classical Muslim State", Islamic Studies 1 (1962), 90.

28. Cf. Kamali, "Characteristics", 32.

29. Ibid., 33; 'Awwā, al-Fiqh, 6:170-1.

30. Joseph Schacht, "Islamic Law in Contemporary States", The American Journal of Comparative Law 8 (1959), 19.

31. Muhammad Rashīd Riḍā, Fatāwa Imām Muhammad Rashīd Ridā, comp. Șalāḥ al-Dīn Munjid and Yūsuf Khur̄̄ (Beirut: Dār al-Kitāb al-Jadīd, 1390AH/1970), 805-8; Maḥmūd Ḥilmī Muștafā, Niz̄ām al-hukm al-islāmī (Cairo: n. publ., 1401AH/1981, 6th ed.), 122.

32. Cf. 'Abd al-Wahhāb Khallāf, al-Siyāsah al-shar 'iyyah (Cairo: al-Maṭa'ah al-Salafiyyah, 1350AH/1970), 59; Umar Chapra, The Economic System of Islam (Karachi: University of Karachi Press, 1971), 63; Kamali, "Characteristics", 33.

33. Abū Yūsuf Ya 'qūb b. Ibrāhīm, Kitāb al-kharāj (Cairo: al-Mațba 'ah al-Salafiyyah, 1352AH/1933, 2nd ed.), 152; Abū 'l-Ḥasan al-Māwardī, Kitāb al-ahkkām al-sulțāniyyah (Cairo: al-Babi al-Halabi, 1386AH/1966, 2nd ed.), 194.

34. Cf. Kamali, "Characteristics", 37; al-Rīs, al-Nazariyyāt, 377.

35. Muhammad 'Abduh, al-Islām wa 'l-nașrāniyyah (Cairo: Dār al-Manār, n.d., 8th ed.), 57-58; see also Mutawallī, al-Sharì'ah, 208-10.

36. Maḥmūd Shalțūt, al-Islām: 'Aqīdah wa sharī'ah (Kuwait: Dār al-Qalam, 1965), 476.

37. al-Qaraḍ̄āī, Min fiqh al-dawlah, 57-8; See also Qadri, Islamic Jurisprudence, 270 n. 29.

38. Hasan Turabi, "The Islamic State", in: John Esposito (ed.), Voices of Resurgent Islam (New York: Oxford University Press, 1983), 243.

39. Salem Azzam (ed.), Islam in Contemporary Society (London: Longman, 1982), 258.

40. Sayyid Quțb, al- 'Adālah al-ijtimā 'iyyah fì 'l-Islām (Cairo: 'Īsā al-Bābī al-Halabīi, 1373AH/1954, 2nd ed.), 98 .

41. See for the text (in 47 articles) and analysis of the main features of the 'Constitution of Medina', Fu'ād 'Abd al-Mun 'im Aḥmad, Ușūl niz̄ām al-hukm fì 'l-Islām (Alexandria: Mu'assasah Shabāb al-Jāmi 'ah, 1411AH/1991), 92-7; Munīr Ḥāmid al-Bayāțī, al-Niz̄ām al-siyāsī al-islāmī muqārinan bi-'l-dawlat al-qānūniyyah (Baghdad: Dār al-Bashīr li'l-Nashr wa-'l-Tawzī' , n.d.), 46.

42. Cf. 'Abd al-Karīm Zaydān, al-Fard wa 'l-dawlah fì 'l-sharī'ah al-islāmiyyah (Gray IN: International Islamic Federation of Student Organisations, 1390AH/1970, 2nd ed.), 7.

43. Cf. 'Abd al-Hamid Mutawallī, Mabādī niz̄ām al-ḥukm fì 'l-Islām (Alexandria: Munsha'āt al-Ma'ārif, 1974), 92f. 
44. 'Uthmān, al-Fikr, 30, 119.

45. al-Qaraḍ̄̄ī, Min fiqh al-dawlah, 31, 34.

46. Cf. Ibn al-Athīr, al-Bidāyah wa 'l-nihāyah (Beirut: Maktabat al-Ma'ārif, n.d.), 17:180.

47. al-Qaraḍ̄̄wī, Min fiqh al-dawlah, 60, 66; Fahmī Huwaydī, "Akdhūbat al-ḥukm al-ilāh $\bar{\imath} "$, Al-Ahrām [Cairo], 14 October 1986, as quoted by al-Qarạ̦āwī, Min fiqh al-dawlah.

48. Mutawallī, Mabādī, 190.

49. al-Qaraḍāwī, Min fiqh al-dawlah, 68-70 (therein also referring to Jalāl al-Dīn al-Suyūṭī, Ta 'rīkh al-khulafä' (Beirut: Dār al-Fikr, n.d.), 241).

50. Ibid., 72.

51. Cf. Z̄āir al-Qāsimī, Niz̄ām al-ḥukm fì 'l-sharī'ah wa 'l-ta'rīkh (Beirut: Dār al-Nafă's, 1977, 2nd ed.), 297; Ann K.S. Lambton, State and Government in Medieval Islam (Oxford: Oxford University Press, 1981), 298.

52. Ziba Mir-Hosseini and Richard Tapper, Islam and Democracy in Iran: Eshkevari and the Quest for Reform (London: I.B. Tauris, 2006), 89.

53. For a recent survey of Twelver Shi ite beliefs and practices see Christoph Marcinkowski, Shi ite Identities: Community and Culture in Changing Social Contexts (Freiburg Studies in Social Anthropology 27 (Zurich: LIT Verlag, 2010), 19-48. See also Christoph Marcinkowski, "Twelver Shi ite Islam: Conceptual and Practical Aspects", IDSS Working Paper 113 [Institute of Defence and Strategic Studies, S. Rajaratnam School of International Studies, Singapore], July 2006, available online at http://www.rsis.edu.sg/publications/WorkingPapers/WP114.pdf (accessed on 2 April 2010).

54. Marcinkowski, Shi ite Identities, 26.

55. See Said Amir Arjomand, "Crisis of the Imamate and the Institution of Occultation in Twelver Shi'ism: A Sociohistorical Perspective", International Journal of Middle East Studies 28, no. 4 (1996), 491-515, idem, "The Consolation of Theology. The Shi' ite Doctrine of Occultation and the Transition from Chiliasm to Law", Journal of Religion 76, no. 4 (1996), 548-71, and idem, "Imam Absconditus and the Beginnings of a Theology of Occultation: Imami Shi' ism around 900 CE/280-290 AH", Journal of the American Oriental Society 117, no. 1 (1997), 1-13.

56. V. Klemm, "Die vier sufarā' des Zwölften Imam. Zur formativen Periode der Zwölferš̄'‘a", Die Welt des Orients 15 (1984), 126-43.

57. For an early Twelver Shi ite source see Abdulaziz Sachedina, "A Treatise on the Occultation of the Twelfth Imamite Imam", Studia Islamica 48 (1978), 108-24.

58. Already in 944, only three years after the beginning of the 'major occultation', a tomb with a mosque (later known as al-'Askariyyah) was erected on the burial site of the eleventh Imām. In the further course of history, a magnificent golden dome was constructed above the tomb which was destroyed by Sunnite extremists in February 2006. This event has subsequently led to the outbreak of widespread sectarian violence throughout Iraq.

59. al-Shāwī, al-Mawșū 'ah, 2:105, n. 31.

60. Cf., Mir-Hosseini and Tapper, Islam, 89.

61. As quoted in ibid., 91.

62. al-'Awwā, al-Fiqh, 71-2.

63. Muḥammad Mahdī Shams al-Dīn's views are conveyed in his two works Niz̄ām al-hukm wa 'l-idārah fì 'l-Islām (Beirut: al-Mu'assasah al-Dawliyyah, 1995) and F̄̄ 'l-Ijtimā' al-siyāsī al-islāmì (Beirut: al-Mu'assasah al-Jāmi 'iyyah li'-Dirāsāt wa'l-Tawzī', 1992) - cited by both al- 'Awwā and al-Shāwī, as in the following notes.

64. al-Shāwī, al-Mawșū 'ah, 1:106.

65. Hamid Enayat, Modern Islamic Political Thought (London: Macmillan, 1982), 126.

66. Ibid., 128.

67. Ibid., 135.

68. al-Qurshī, Niz̄ām al-ḥukm, 104f.

ICR 2.1 Produced and distributed by Pluto Journals ICR.plutojournals.org 
69. Both Taha Husayn and Muḥammad Husayn Haykal's views are quoted in Mazheruddin Siddiqi, Modern Reformist Thought in the Muslim World (Islamabad: Islamic Research Institute, 1982), $132-3$.

70. al-Rīs, al-Naẓariyyāt, 372-85.

71. Țurābī, "The Islamic State", 244.

72. al-'Awwā, al-Fiqh, 60.

73. Ibid., 61; al-Qurțubī, Tafsīr al-Qurțubī (Beirut: Dār al-Kitāb al-'Arabī, 1997), 4:249.

74. For details on ijmā' see Mohammad Hashim Kamali, Principles of Islamic Jurisprudence (Cambridge: The Islamic Texts Society, 2003), 228f.

75. Zaydān, al-Fard, 25. For further detail on sovereignty see Mohammad Hashim Kamali, "The Limits of Power in an Islamic State”, Islamic Studies 28 (1989), 324; Wașfī, al-Nizām, 17.

76. al-Rīs, al-Nazariyyāt, 385 .

77. Cf. Wașfī, al-Nizām, 97-8; al-Shāwī, al-Mawșū 'ah, 1:106 and 2:452.

78. al-Qaraḍ̄̄ī, Min fiqh al-dawlah, 48-9.

79. Muhammad Asad, The Principles of State and Government in Islam (Berkeley CA: University of California Press, 1961), 17.

80. al-Qaraḍ̄wī, Min fiqh al-dawlah, 130-47.

81. Ibid., 138. See also Mahmud Ahmad Ghazi, State and Legislation in Islam (Islamabad: Shariah Academy, 2006), 53.

82. Eshkevari, as quoted in Mir-Hosseini and Tapper, Islam, 86.

83. Ibid., 85 .

84. Ibid., 147-61.

85. Syed Ameer Ali, quoted in Siddiqi, Modern Reformist Thought, 119.

86. Quoted by Siddiqi, Modern Reformist Thought, 127.

87. Muhammad Iqbal, The Reconstruction of Religious Thought in Islam (Lahore: Ashraf Press, 1982, repr.), 157; see also Siddiqi, Modern Reformist Thought, 127.

88. Siddiqi, Modern Reformist Thought, 128 (quoting Khalīfah 'Abd al-Hakīm, Fikr-i Iqbāl, 266).

89. Asad, Principles, 36.

90. Cf., Mohammad Hashim Kamali, "Characteristics of the Islamic State", Islamic Studies 32 (1993), 31 .

91. Cf., Sa 'dī Abū Habīb, Dirasah fì manhaj al-Islām al-siyāsī (Beirut: Mu’assasah al-Risālah, 1406AH/1985), 72; Taqī al-Dīn al-Nabhānī, Muqaddimāt al-dustūr (Kuwait: Dār al-Qalam, 1964), 89-90.

92. Cf., Ghazi, State, 107f.

93. al-Sanhūrī, Fiqh al-khilāfah, 174-5.

94. Ibid., 179.

95. Wahbah al-Zuhaylī, Qaḍāyā al-fiqh wa 'l-fikr al-islāmī (Damascus: Dār al-Fikr, 2006), 466ff.

96. 'Abd al-Karīm Zaydān, Niz̄ām al-qaḍā fì 'l-sharī'ah al-islāmiyyah (Beirut: Mu'assasah al-Risālah, 2002, 3rd rev. ed.), 59.

97. Ibid., 59-60.

98. Chandra Muzaffar, "What Pluralism Means to Islam", Sunday Star [Kuala Lumpur], 18 June 2006, 28 .

99. Ibid.

100. Mohammad Hashim Kamali, Freedom of Expression in Islam (Cambridge: Islamic Texts Society, 1997), contains a chapter each on 'freedom of religion' (87-106) and 'blasphemy and apostasy' (212-50), respectively. See also my "Diversity and Pluralism: A Qur'ānic Perspective", Islam and Civilisational Renewal 1, no.1 (2009), 27-55.

101. Yūsuf al-Qaraḍāwī, "al-Ta addudiyyah fī naẓar al-Islām”, in the conference proceedings volume Niz̄ām al-ḥukm al-islāmī wa 'l-dīmūqrātiyyah: al-furūq wa imkāniyyāt al-ta 'āyush (Amman: Mu'assasat Āl al-Bayt li’ l-Fikr al-Islāmī, 1424 AH/2004), 8.

102. Cf., Joseph Lumbard, “Qur'anic Inclusivism in an Age of Globalisation”, in: Muhammad Suheyl Umar (ed.), The Religious Other: Towards a Muslim Theology of Other Religions in a Post- 
Prophetic Age (Lahore: Iqbal Academy Pakistan, 2008), 154. Lumbard also quotes Jane Dammen McAuliffe, Qur'anic Christians: An Analysis of Classical and Modern Exegesis (Cambridge: Cambridge University Press, 1992), and Yohanan Friedmann, Tolerance and Coercion in Islam: Interfaith Relations in the Muslim Tradition (Cambridge: Cambridge University Press, 2003). See also Anthony H. Johns and Abdullah Saeed, "Nurcholish Madjid and the Interpretation of the Qur'an: Religious Pluralism and Tolerance", in: Suha Taji-Farouki (ed.), Modern Muslim Intellectuals and the Qur'an (Oxford: Oxford University Press, 2004), 86-7.

103. Cf., 'Abd al-Wahhāb Khallāf, as quoted in Mutawallī, al-Sharī'ah, 224 n. 1. See also al-Rīs, al-Nazariyyāt, 210; for further details on some of these principles see Mohammad Hashim Kamali, Freedom, Equality and Justice in Islam (Cambridge: The Islamic Texts Society, 2002). 